\title{
Literacy of Islamic Thought: Contestation, Claim of Truth, and Polemic of Religion in Islam in Gorontalo, Indonesia
}

\author{
Samsi Pomalingo ${ }^{1} \square$ Nurul IImi Idrus ${ }^{2}$, Mohammad Basir ${ }^{3}$ and Mashadi ${ }^{4}$ \\ ${ }^{1}$ Faculty of Education, Universitas Negeri Gorontalo, Indonesia \\ ${ }^{23}$ Faculty of Social and Political Sciences, Universitas Hasanuddin, Makassar, Indonesia \\ ${ }^{3}$ Faculty of Usuluddin and Da'wah, IAIN Sultan Amai Gorontalo, Indonesia
}

$\square$ Corresponding Author: Samsi Pomalingo, E-mail: samsipomalingo789@gmail.com

\section{ARTICLE INFO}

Received: 12 October 2021

Accepted: 26 November 2021

Published: 14 December 2021

DOI: 10.32996/ijcrs.2021.1.1.8

\section{KEYWORDS}

ANSOR, PMII, Wahdah Islamiyah, Tablighi Jamaat, Polemic

\section{ABSTRACT}

As many previous studies tend to discuss the biography of local Islamic figures and overly-textual interpretation in exploring the Hizb ut-Tahrir Indonesia and criticize the western concepts of democracy in Gorontalo, this study aims to explore the newlyfound dynamics of contestation of local Islamic thought in Gorontalo Province. Conducting in Gorontalo, a northern province in Sulawesi Island inhabited mainly by Muslim communities, this study employs a qualitative approach with a descriptive method. In the present work, the discourse of Islamic thought in Gorontalo is found to develop into a massive and uncontrolled state, leading to polemics among the Muslim community in the area. The polemics among people, including in the social media, involve two groups that are ideologically and epistemologically different: the liberal Islamic groups, i.e., ANSOR and PMII, and the fundamental Islamic groups, i.e., Tablighi Jamaat and Wahdah Islamiyah. Issues of religion-culture debate, khilafiyah, religious pluralism, and prohibition of Christmas salutation are among the main highlights of the polemic, especially among Muslims in Gorontalo. The presence of fundamentalists represents the new phenomenon in the Islamic thought discourse in Gorontalo, which is known for its subjectivity in perceiving the absence of the basic principles or nash (Qur'an and hadith) of the fundamentalists. Consequently, a debate between the two groups, claiming which one has the absolute truth, is inevitable. This situation also ends up with fundamentalist extremism labelling others as infidels (takfiri) and deviant to Islamic teachings.

\section{Introduction}

Indonesia is a diverse country with an abundance of cultures and ethnicities. This is seen in the State's ideology Bhinneka Tunggal Ika that resembles "unity in diversity". Such a portrait of diversity does not come out of a vacuum space; rather, it results from a long process of assimilating two contradicting thoughts and perspectives, specifically in the view of religious thoughts. This process later forms a transforming ideology in a movement of thought (or harokah). Agus Salim, a famous scholar, views the religion of Islam as the solution to all problems of Muslims in their social and State life (Ghufron, 2016). Islam later serves as a driving force to instill awareness and collective solidarity among Muslim people (ukhuwah al-Islamiyah).

The manifestation of the Islamic spirit by Agus Salim, at the time, clashed with other figures and Islamic movements that separate the concept of state life, including habits that represent culture and religion. Soekarno, the first president of Indonesia, was assumed as one of the figures that opposed the vision of Agus Salim. He did not allow a monopoly of groups affiliated with religious ideologies, including Islam, to take place within the State. With his secular-nationalist movement, Soekarno formulated ideas that fit best with the situation in Indonesia through a concept of nationalism. The concept upholds the spirit of citizenship that covers diverse races, religions, cultures, and other social cohesion aspects.

Copyright: (c) 2021 the Author(s). This article is an open access article distributed under the terms and conditions of the Creative Commons Attribution (CC-BY) 4.0 license (https://creativecommons.org/licenses/by/4.0/). Published by Al-Kindi Centre for Research and Development, London, United Kingdom. 
The rationale behind the separation of religion and state life is that religion is a private matter. Religion is a space where a person can perform their religious practices. Such is not to be bound by theological reasons, as religion or the faith to transcendental beings is the right of all people. People have the right to practice their religion. People who have assimilated themselves with religious values always provide a space to reflect on their spiritual achievement.

Problems of religion had changed after Soekarno's reign, and the separation of religious concepts and state life seemed ambiguous. During the New Order under Soeharto's regime for 30 years, people lived under military repression. All religious activities were under surveillance and considered suspicious, and religious figures could not do something as any people involved in resistance movements ended up in jails. Such conditions confirm that people practising their religious activities in the New Order were confined by inequitable laws. Many religious gatherings in cities were deemed suspicious acts that threatened the State (government). The suspicion was based on the movement and resistance of Sekarmadji Maridjan Kartosoewirjo, an Indonesian Islamic figure who led the Darul Islam (DI/TII NII) rebellion.

When the democratic space opened in the reformation era, the Indonesian people were freed from conditions suppressing political, social, and religious activities. The reformation era brings a fresh breeze to the political movement of Muslim communities. The publics' euphoria cannot be contained as all people expressed their gratitude for the freedom of their lives, including their religious activities, from the tyranny of the New Order regime. Freedom of expression has been the right of all citizens as stipulated in Laws. As a result, many religious gatherings in public spaces have formed their groups. These groups symbolize the uniqueness of the Muslim community in Indonesia in practising their religion.

The freedom of religious expression does not always result in spiritual intelligence but also triggers new problems. Diverse ideologies and Islamic movements in Indonesia are prone to polemics. This situation also occurs in Gorontalo, a province formerly a part of North Sulawesi located at the northern part of Sulawesi Island, inhabited mainly by Muslims. The majority of Muslims in Gorontalo affiliate with Ahlul Sunnah Wal Jama'ah (ASWAJA), Nahdliyyin (NU), Muhammadiyah, Serikat Islam, Al-Khairat, Wahdah Islamiyah, Tablighi Jamaat, and Salafist group.

\section{Methodology}

This study was conducted in Gorontalo, a northern province in Sulawesi Island inhabited mainly by Muslim communities. It explores the newly-found dynamics of contestation of local Islamic thought in the province. Previous studies tend to discuss the biography of local Islamic figures and overly-textual interpretation in exploring the Hizb ut-Tahrir Indonesia and criticize the western concepts of democracy in Gorontalo. Such signifies the typicality and artificiality of the research.

\section{Results and Discussion}

\subsection{Polemics and Claim of Truth}

Polemics in Islamic thought in Gorontalo involve religious groups with different ideologies and views. Such a problem has been around for a long time, and it results in different thoughts, organizations, and movements that continuously change. The unending contestations also bring diverse identities and thoughts to the movements or groups: right-extremists, left-extremists, and moderates (al-wasathiyah). Pluralism in Islamic thoughts is a trait that characterizes the spirit of post-modernisms. This is because postmodernism opposes the diversity of thoughts in any discourses, including religious thought (Ismail, 2019).

All three groups of Islamic movements previously mentioned have started to spread in Gorontalo. Nahdlatul Ulama (henceforth, $\mathrm{NU}$ ) and Muhammadiyah are considered moderate Islamic organizations, PMII and ANSOR are liberal Islam groups, and Wahdah Islamiyah and Tablighi Jamaat are considered fundamentalists. Young NU activists (PMII and ANSOR) are in conflict with Wahdah Islamiyah and Jama'ah Tablighi. With their collective goals, these groups are in dispute of truth claim. Often these conflicts lead to endless polemics. These two groups are like two sides of a coin that are never in a mutual agreement (kalimatun sawa).

Claims of truth over the opinions and existence of groups are seen as a typical sociological phenomenon. Blaming and subordinating one another is the effect of the presence of a single truth. Polemics in Islam have occurred between Al-Ghazali and Ibn Rushd, but the two of them did not claim which one has the absolute truth. The two scholars debated the philosophy about the Existing (the Qadim of Nature). Al-Ghazali wrote a book on Tahafutut Alfalasifah (the confusion of philosophers' thoughts) to refute Ibn Rushd's work entitled Tahafutut at Tahafut, which responded to al-Ghazali's refutation of the thoughts of philosophers that are not allowed in the religion (Mulyadi, 2008).

Debates among the Muslims in Gorontalo end in claiming others as disbelievers (takfiri) or the infidels. An example of this problem is the tawassul case generally carried out by traditionalist scholars, especially NU (Rohmana, 2017). Claims of truth based on hegemony as the group that understands the Qur'an and Hadith the best tend to position other groups as wrong, heretical, and infidels. This tendency is found in several followers of fundamentalists, such as Wahdah Islamiyah and Tablighi Jamaat in Gorontalo.

Wahdah Islamiyah is an Islamic organization that follows the understanding of As Salaf Ash-Salih or Manhaj Ahlussunnah Wal Jamaah as the basis of the understanding and practice of the Qur'an and Sunnah. This organization focuses on several aspects, ranging from da'wah, education, social, women empowerment, health to the environment. Talqqiyan (masdar) is a source of 
learning religion in monotheism, aqidah, and manhaj (methodology of receiving, analyzing, and applying knowledge) of thought. According to the view of Wahdah Islamiyah, talqqiyan applies to all Muslims. In principle, talqqiyan is an attempt to approach (wa qaribu wa saddidu) practices that the Prophet Muhammad PBUH did.

Talqqiyan considers the Qur'an and Sunnah as a source that exceeds dalil aqli (reasoning). The central board of Wahdah Islamiyah has compiled a book entitled "Aqidatuna wa Manhajuna" (Our Aqidah and Our Manhaj). This book explains about the followers of the Sunnah (ahlus Sunnah wal jamaah) who cling to the Sunnah of the Prophet Muhammad PBUH and the companions who always follow the true path, word and deed of Prophet Muhammad. They were steadfast in following the Sunnah and staying away from bid'ah (innovation) until the Day of Judgment.

Wahdah Islamiyah has several assemblies or majlis ilm in many mosques as a da'wah organization. The assemblies' agenda mostly discusses Tawheed (unification or oneness of God) and figh (the human understanding and practices of the sharia). Fiqh, however, has been the topic frequently discussed among Muslim communities in Gorontalo. Both Wahdah Islamiyah and Tablighi Jamaat are well-known for their mission to encourage Muslims to revert back to Qur'an and Sunnah. They reject takhayul (superstition), bid'ah (innovation in performing religious activities), and khurafat (absurdity) as a manifestation of purifying the teachings of Islamic from local cultures. On the one hand, NU approaches the locals through the traditions of its members. Such an approach is slightly different from the Tablighi Jamaat, in which the group does not focus on the issues of khilafiyah (different views in approaching a specific aspect). The principle of Tablighi Jamaat is to spread the practice of the Prophet's Sunnah, and thus the group avoids everything that can distract its members from obeying Allah the Almighty.

Furthermore, Tablighi Jamaat does not concern with the difference of schools of thought (madhhab, i.e., Syafi'l, Maliki, Hambali, and Hanafi). Such does not suggest that the members of Tablighi Jamaat do not follow any school of thought. In fact, they are allowed to choose what madhhab they prefer, without debating the idea of those with different madhhab. For the Tablighi Jama'at, khilafiyah is not a topic to argue, as it has been thoroughly discussed by the four great scholars and other scholars. The group claims that practising everything stated in the madhhab is more important than avoiding conflicts.

The debate over the topic of khilafiyah has led to a dispute among Muslims. The priority of Tablighi Jamaat is to instill a sense of brotherhood among Muslims (ukhuwah Islamiyah). Another concern of Tablighi Jamaat is encouraging Muslims to practice religious activities based on Islamic teachings (Junaedi, 2013). Tablighi Jamaat is also known for separating religious matters and politics (Zaeny, 2016). Practical political affairs are not the concern of Tablighi Jamaat. Followers of Tablighi Jamaat are prohibited from getting involved in government-related matters, since the act negatively impacts their da'wah and prevents them from remembering (dhikr) Allah the Almighty. Simply put, Tablighi Jamaat has opposite views than other Islamic movements that utilize politics to gain power.

\subsection{Disputes in the Discourse}

The dynamism of local Islamic thought in Gorontalo is seen as a form of discourse dispute, manifesting the truth claim. However, such dynamism emerges as a part of the polemic. The presence of transnational Islamic movements remarks a new era of the development of local Islamic thoughts in Gorontalo. In this case, transnational Islam refers to Islamic organizations operating across national boundaries (Aksa, 2017). Transnational Islam is a result of the global situation of the world, including the Islamic world, which at that time was moving towards the modern era (Syaoki, 2017). Further, the existence of transnational Islamic groups, such as Tablighi Jamaat and Salafists in Wahdah Islamiyah Gorontalo, often results in polemics of thought on issues of ideology and figh, or differing views.

The polemic of Islamic thoughts in Gorontalo revolves around five aspects: the debates over religion and tradition, the problem of khilafiyah, state ideology (khilafah), religious pluralism, and the prohibition of wishing Merry Christmas. All of the aspects are discussed in separate sections below.

\subsection{Religion and Tradition}

The majority of people in Gorontalo affiliate with NU, which is famous for its principles in religious called an-nadhdliyah. In terms of socio-cultural perspective, people in Gorontalo still uphold the values of the tradition inherited from their ancestors, as reflected in their philosophy formulated since the era of Matodulakiki (1550-1585): "Adati hulahulaa to saraa, saraa hulahulaa to adati" or "sharia underpinning the tradition', tradition underpinning sharia" (Lipoeto, 1947). This philosophy later changed in the Tradition Seminar in 1971 into "adat bersendi syara' Syara' bersendi Kitabullah." A firm grip on cultures and traditions in Gorontalo is because of an old saying by Ba'ate or traditional leaders and local leaders in the following.
Dahajimu hulalata
Wuudu wawu bubalata
Tuggulo u ilomata
To wombu baata ilata

\author{
: Djagalah olehmu (It is for you to preserve) \\ : Adat istiadat (Our cultures and traditions) \\ : supaya harum namamu (To splendor your name) \\ : sampai pada anak cucumu (to your children and grandchildren)
}


Cultures and traditions formulated and agreed upon by the ancestors are central to the way of life of Gorontalo people in recent and upcoming days. Such a spirit remains the same among people, which symbolizes the goal and perseverance of local people in maintaining their identity amid changes in today's world, since modernization will slowly bring a shift to the local culture, thus replacing the inheritance from the ancestors. Such inheritance has always been a guide for people. However, many have been concerned about a situation where the original, local cultures and traditions should be adjusted with global changes or when the two aspects are assimilated with religion. This resonates with what Raja Eyato, the man with the title of Tato Selongi (Ceylon Island), had concerned long ago, as stated below.

\begin{tabular}{|c|c|}
\hline Didu boli didu boli & : Djanganlah-djanganlah (It is prohibited for you) \\
\hline Adati limongoli & : Kamu punya adat istiadat (On your cultures and traditions \\
\hline Didu boli-bolija & : Janganlah ubah lagi (To change them both) \\
\hline Bo pohutu wolo odije & : Tetapkanlah begitu (Keep them as they are) \\
\hline Wonu bolo boliolo & : Kalau diganti (Changing them means) \\
\hline Lipu tija mo oalo & : Negeri akan cerai berai (the separation of the land) \\
\hline \multicolumn{2}{|c|}{ Suwawa, Limutu, Hulontalo: Suwawa, Limboto, Gorontalo } \\
\hline Djandji tija ngopangga & : Karena janji satu ikatan (Because of one unifying $p$ \\
\hline
\end{tabular}

This philosophy of life embodies the idea, norm, social capital, inner attitude, and way of life that become the basic ideology of Gorontalo people. Many have endeavored to have the philosophy remain in the social life of Gorontalo people who are diverse in structure and social status. The spirit to carry out positive customs is a part of the accommodative attitude of NU towards traditions as stated in the rules of figh "al-muhafadhotu 'ala qodimis sholih wal akhdzu bil Jadidil Ashlah", (maintaining the past positivity and implementing the new, better values). For NU, preserving traditions and cultures can support the spread of religious teachings, as cultures are considered the infrastructures of religions.

The approach of NU in perceiving traditions results in counterarguments from Islamic puritan movements, e.g., Wahdah Islamiyah. According to the local context, traditions are inseparable from religions. Some traditions associate with certain religions, e.g., modutu (a ritual where the groom brings marriage gifts to the bride), molonthalo (a ritual for the safe passage of a woman's first seven months of pregnancy), molihu lo limu (a bathing ritual using lime water when a girl enters her early adolescent age), and beati (rite of passage into adolescence for young women).

The presence and practice of some of the traditions previously mentioned, including dikili (dzikr), mauludu (mawlid celebration), me'eraji (Isra' mi'raj commemoration), aruwa (prayer for deceased families), ngadi salawati (reciting salawat), tahlili (similar to aruwa), and tawasul prayers, have received resistance from the Islamic puritan movement (Wahdah Islamiyah). Wahdah Islamiyah considers that all of those practices are against the teaching of Islam and the Sunnah of Prophet Muhammad PBUH. The movement also labels the followers of NU as ahlul bid'ah (alleged Muslims who bring to the Islam religion a practice which is not mentioned in the Holy Qur'an or approved in the Prophet Muhammad's Sunah).

Wahdah Islamiyah considers that Islamic teachings must be freed from the influence of local culture or actions that the Prophet never exemplified. This is simply to maintain the purity of Islamic teachings taught by the Prophet Muhammad and the salafu ummah (generations of companions and tābi'ūn, or "followers and successors" of Muslims who followed the Companions of the Prophet Muhammad). However, Muslims in Gorontalo consider that their traditions must be maintained and preserved as the traditions are claimed to be based on, and do not violate, the sharia.

Polemics of traditions have received less attention from traditional councils, suggesting that the issues are less-concerning. However, religious leaders, especially from NU, have shown a more significant concern for polemics. NU activists opine that the puritan exaggerates things and lacks understanding regarding good traditions. The activists refer to the idea that traditions are a part of the spirit of Islamic teachings (al-muhafadhotu 'ala qodimis sholih wal akhdzu bil jadidil ashlah) as interpreted by the Wali Sanga (the saints of Islam in Java).

For the NU community, tradition as a religious infrastructure serves as the driving force to keep the spread and practice of Islamic teachings. However, Wahdah Islamiyah opposes the assimilation of Islamic teachings with tradition or culture. They believe that masdar talaqqi is the only source of the practice of religious activities. The followers of Wahdah Islamiyah in Gorontalo, for example, do not incorporate some rituals in their wedding, e.g., mongilalo (observing), mohabari (explaining the intention of marriage), baalanga (informing the date of marriage proposal), modutu (bringing marriage gifts to the bride), modepita maharu (bringing the dowry) and modepita dilonggato (food) (Mantau, 2016). Marriage among the followers of Wahdah Islamiyah is also well-known for using veil (hijab) separating the men and women guests. This practice motivates them to draw closer to the Prophet Muhammad's Sunnah.

Young NU activist groups, involving the Indonesian Islamic Student Movement (PMII) and ANSOR, consider no syncretization between Islamic teachings and local culture. They spot a difference between Islamic teachings and culture since Islamic teachings 
are sourced from the Qur'an and hadith. In contrast, culture is human creations based on their interactions with the environment. Young NU activists, however, claim that traditions can be part of religious rituals or practices as all of the practices are based on the legal rule of "al'adatul muhakkamat" (traditions are law), meaning that traditions or urf (tradition) is a part of the source of Islamic law. This issue has been debated among the activists, especially regarding religion and tradition matters.

\subsection{Khilafiyah}

Islam upholds the concept of brotherhood or ukhuwah. This is underpinned by the teaching in Islam that all Muslims are depicted as one. Differences of opinion, as long as everything is based on Qur'an and Sunnah, will not break the concept of brotherhood and unity. Many practices of mahdhah (every worship that is from Allah and His messengers) and ghairu mahdhah (worship purposed to approach Allah) differ from one school of thought to another. Such differences often lead to the interest of a particular group.

The majority of Muslims in Indonesia follow Shafi'i school (madhhab). Fanaticism towards one madhhab leads to close-minded, although often, the case does not involve the denial of the presence of madhhab, e.g., the Maliki, Hanafi, and Hambali. The problem of khilafiyah has long been discussed among figh scholars since the death of the Prophet Muhammad. However, the issue is considered resolved by some mutaakhirin (present-day scholars) since mutaqoddimin (past scholars), such as the imams of the four schools of thought, had not questioned the topic of khilafiyah. The only task of today's Muslims is to select which school of thought they will follow.

These days, the situation is different as many Muslims still debate different views of one madhhab to another. For instance, many clerics in Gorontalo were involved in a polemic between NU and Muhammadiyah in the 1960s (Subair, 2015). The debate lasted until the 1970s and 1980s. Recently, many Muslims have continued to debate the khilafiyah issues. Some prefer to reinterpret religious texts (Qur'an and hadith, and opinions of scholars) to adapt to continuous changes in today's world. The aim is not to force religion to comply with the dynamics of the world. It aims to promote the awareness that religion offers solutions to society's increasingly complex problems, e.g., pluralism, tolerance, and religious freedom.

NU and Muhammadiyah, established in the 1930s or the "Old Islam" era, became the leading social organization by the majority of the Muslim community in Gorontalo. In addition to these two organizations, some Salafists later established their mass organizations, namely Wahdah Islamiyah and Tablighi Jamaat, in the 1990s. Both organizations are considered "New Islam groups."

Wahdah Islamiyah and Jama'ah Tablighi encourage all Muslims to follow everything Prophet Muhammad PBUH has modeled and stated in his Sunnah, from waking up to going back to sleep, e.g., eating, drinking, performing salat, and transacting. The presence of the two organizations, specifically Wahdah Islamiyah, is considered a response to Islamic teachings' purification. Some Muslim communities argue that the emergence of this organization may trigger a debate in furu' (branch) issues between Muhammadiyah and $\mathrm{NU}$ at that time.

Khilafiyah is one of the topics of science in fiqh or Islamic law, which covers furu'iyah (branches) issues, i.e., a topic debated mainly by many Islamic organizations in public spheres and social media. Some examples are the debate regarding qunut, tahlilan, grave pilgrimages, and tawasul. The polemic is based on the presence or absence of a proposition or an example from the Prophet Muhammad PBUH regarding a specific issue. The debate of such a topic can also be found in one of the Facebook groups named Portal Gorontalo, which was initially created as a marketplace, and a WhatsApp group called Gorontalo Bersyari'ah (which discusses another topic, including the state ideology).

Conflicts between two different groups (Wahdah Islamiyah and Tablighi Jamaat, young NU activists, i.e., PMII and Ansor, ex-Hizb ut-Tharir or HTI and ex-Wahdah Islamiyah) is inexorable. Such is due to the proposition of each group (the Qur'an and hadith) as a reference for religious practices. An egocentric, irrational attitude causes this endless, even emotional debate.

Intellectual arrogance often corners each other with dishonor or judges one group as misguided and misleading. Such issues are even common among young Muslims who have studied Islam. The indicator of a truth claim is manhaj; Salafists are labeled as the "Sunnah" group, which some perceive as the authentic practitioners of Islam. Such results in the label of "the Sunnah group" and "Sunnah ustaz" (or clerics), and even a group called PCS or Polisi Cinta Sunnah. Polemics of the debate between the two groups in social media, e.g., WhatsApp and Facebook, mostly involve anonymous accounts.

Wahdah Islamiyah is favored by middle-class groups (students and university students) because they are concerned for the Prophet Muhammad's Sunnah and efforts to purify the teachings of Islam. It is not surprising that their da'wah tends to discuss Sunnah and khilafiyah, and this tendency often receives criticism from the young NU activists. For PMII and Ansor, khilafiyah is no longer relevant to be debated. They urge to focus on humanity problems, such as poverty, corruption, and environmental issues.

\subsection{State Ideology (Khilafah)}


In the modern era, individual rights and social elements are increasingly considered, and a representation based on religious groups is difficult to actualize. The reason underlying such a problem is weakened totalitarianism, in which religion continuously loses its existence should it compete with human interests. As part of the religion from the past, Islam is considered to retain previous psychology and logic. These aspects are inseparable from the classical problems religion faces in today's world.

As a response to several problems previously mentioned, Hizb ut-Tahrir Indonesia or HTI was disbanded based on the Government Decree Number 2 of 2017 Concerning Community Organization. HTI has turned out to be intending to change the ideology of the State, namely Pancasila, with khilafah or a caliphate system. Although it has been disbanded, the followers of HTI still exist. Ex-HTI activists believe that implementing the caliphate system as a state ideology is mandatory as based on Qur'an stating that "la hukma illa lillahi" (there is no law but Allah's law). The motto of HTI is "To Preserve Islamic Life" (Hayati, 2017). Khawarij perspective associate with HTI. Everything must be based on the Qur'an and hadith.

The presence of ex-HTI activists can still be tracked on social media. One example is a WhatsApp group called "Gorontalo Bersyari'ah." The group with 128 members (not all members are ex-HTI) discusses the issue of the caliphate system. The intention of this HTI group to replace Pancasila with the caliphate system receives sharp critics from young NU activists. The activists, involving PMII and Ansor, believe that The Unitary State of the Republic of Indonesia or NKRI cannot be replaced with other state systems at all cost. Such also applies to Pancasila as the state ideology, since this ideology serves as a medium to unite diversity (races, religions, cultures, languages, and ideology) or later coined as kalimatun sawa or mutual agreement. For young NU activists, Indonesia does not have to be an Islamic state, although the majority of its population is Muslim.

Ex-HTI activists in Gorontalo underwent gradual changes in terms of their identity. They are more likely to mingle with anyone and, at the same time, strive to promote the concept of the caliphate. Tablighi Jamaah followers are easily indoctrinated to the ex-HTI's propaganda or the commercialization of the doctrine with the label hadith khilafah ala Minhajin nubuwah (as the lovers of the Sunnah of the Prophet). The upholding of the spirit of Islam is a necessity of the caliphate system, a solution to socio-political life in the Islamic world. Such action is considered a manifesto of the actualization of obedience to the Islamic teachings.

\subsection{Religion Pluralism}

Discussing pluralism topics is of paramount importance since such issues correlate with social and religious life. Indonesia is inhabited by people from different tribes, ethnicities, languages, cultures, and religions, making the population sociologically and anthropologically plural. Pluralism is considered an asset that must be protected. On the other hand, plural countries are prone to detrimental problems (Pomalingo, 2019). Such ambivalence becomes a concern that requires solutions to maintain plural countries' unity.

The definition of pluralism has been proposed by many comparative religious experts and religious thinkers, among the example is from John Hick:

"...pluralism is the view that the great world faiths embody different perceptions and conceptions of, and correspondingly different responses to, the Real or the Ultimate from within the major variant cultural ways of being human; and that within each of them the transformation of human existence from self-centeredness to Reality centredness is manifestly taking place and taking place, so far as human observation can tell, to much the same extent" (Hick, 1989).

From religious perspectives, pluralism views that religions are equal, although they have different approaches (Madjid, 2001). For Madjid, pluralism should not be comprehended merely as a "negative virtue." Pluralism must be regarded as "genuine engagement of diversity within the bounds of civility."

The discourse on religious pluralism heated up in Gorontalo in 2005 since the return of Gorontalo students studying at Gadjah Mada University. Ever since then, religious pluralism has been a discussion topic in university seminars and other events, such as interactive dialogues on the radio. At first, the events have attracted many concerned with pluralism, especially university students and PMII activists.

PMII has been the pioneer of religious pluralism in Gorontalo. Religion pluralism has been an issue primarily discussed in many forums. Universitas Negeri Gorontalo and State Islamic Institute of Sultan Amai are the centers of knowledge transfer that promote awareness of students regarding the importance of pluralism discourse as the issue is new in Gorontalo. As a result, forums and discussions on religious pluralism have received attention from local Muslim communities, e.g., Wahdah Islamiyah and ex-HTI activists. Ishak Bakari represents Wahdah Islamiyah, and Mustajab Almusthafa represents HTI Gorontalo. The two prominent figures often get involved in religious pluralism forums.

The rejection of religious pluralism emerged after the Indonesian Ulema Council (MUI) issued a haram fatwa on Secularism, Pluralism, and Liberalism (SEPILIS) in 2005. Many academics, students, and followers of Islamic organizations have criticized such an action. The decision of MUI is due to a claim that pluralism is a big project of the United States (Jews) in separating Muslims from Islamic thought and aqidah. Religious pluralism is considered a form of the transcendental unity of religions associated with Western postmodernism. Although considered necessary, tolerance in Islam does not mean that all religions are valid and equal. 
Wahdah Islamiyah perceives that not all religions accept such an opinion. Islam acknowledges the freedom of religion (la ikraha fi dien). Allah the Almighty grants humans freedom of religion and, at the same time, warns humans regarding which religion is rightful (qod tabayyana ruydu minal gayyi). This notion emphasizes that the religion in the sight of Allah is Islam.

Tablighi Jama'ah takes a passive position in seeing the struggle of thought (ghazwul al fikr) among today's Muslims in Gorontalo. In their view, getting involved in such discourse only keeps them away from da'wah and Allah the Almighty. The Tablighi Jamaat also opt not to discuss differences in ethnicity, race, and social status.

Wahdah Islamiyah is very responsive in refuting the practice of religious pluralism amid the dynamism of the development of local Islamic thought in Gorontalo. This is seen in the internal strengthening through intensive Islamic studies to the activists. Further, the organization continuously strives to express its refusal by internalizing the values of monotheism and the Islamic faith. In response to Wahdah Islamiyah's actions, PMII and ANSOR have accused the organization of being a group of people with a lack of understanding regarding the sociological map of the Indonesian nation. They also claim that Wahdah Islamiyah tends to be sectarian and partial in comprehending the discourse of religious pluralism. For young NU activists, pluralism is a necessity and is given by Allah the Almighty (sunatullah) that every people must accept.

Young NU activists see religious pluralism as a discourse of equality in sociological and theological aspects. Understanding of pluralism concept is the reason where God created diversity, as stated in the Qur'an. Such differing opinions highlight the conflicting ideas involving theological arguments underpinned by each proposition. Thus, religious pluralism has long been a part of conflicts, claims of truth involving two organizations with different views.

\subsection{Polemics of Christmas Salutation}

Wishing Merry Christmas from interfaith circles to Christians is a religious reality in Indonesia, similar to other religious holidays. Such represents the pluralism of Indonesia as a diverse country and the effort to maintain interfaith peace. Mutual respect is deemed social capital in maintaining social order and the integrity of the Unitary State of the Republic of Indonesia. Awareness to maintain unity and integrity in society embodies the third principle, namely the unity of Indonesia.

Wishing Merry Christmas has become a discourse in classical fiqh and contemporary fiqh. There are two opinions regarding the polemic of wishing merry Christmas: the one that forbids (textual views) and the one that allows (contextual views) Muslims wishing Merry Christmas (Aspandi, 2018). An example of the textual aspect cites the opinion of Ibn Taimiyah, Ibnul Qoyyim, and their followers, e.g., Sheikh Ibn Baaz, Sheikh Ibn Utsaimin claiming that it is forbidden to wish a Merry Christmas because such an action symbolizes Christianity. On the other hand, some contemporary scholars allow Muslims to wish Merry Christmas. Among the example is Syeikh Yusuf Qaradawi and Quraish Shihab (Arib, 2016). Differences in the scholars' paradigm are common, indicating the hallmark of the figh scholars.

In Gorontalo, wishing others Merry Christmas has been a polemic among Muslims, especially young NU activists and their rivals Wahdah Islamiyah and Tablighi Jamaat. This is because young NU activists claim that believing in Jesus is an obligation for Muslims. On the contrary, Wahdah Islamiyah and Tablighi Jamaat opine that those who intentionally wish others Merry Christmas are considered apostates.

Debates between two opinions are common in social media, and each group insists on their opinion, which is mutually reinforced by religious arguments of scholars. Such tension leads to claiming others as misguided (takfiri) by activists of Wahdah Islamiyah. On the other hand, young NU activists label Wahdah Islamiyah as conservative, unable to understand issues of pluralism in Indonesia, and prerogative in interpreting the religion (the Qur'an and hadith).

\section{Conclusion}

This study explores the newly-found dynamics of contestation of local Islamic thought in Gorontalo Province. The truth regarding an opinion is often claimed by a group that considers itself to be the one with absolute truth. Such a truth claim often resulting in polemics among Muslims covers the area of figh and the issue of a state ideology (khilafah). The argumentative group that has a right or privilege in interpreting the Qur'an and hadith tends to claim to be more Islamic than others. This becomes an issue for some Muslims in Indonesia. Labelling others as misguided becomes more common in public spheres and social media. To worsen, the polemic results in some activists becoming antipathetic towards others with different views. In the end, polemics in Islamic thought in the contemporary era are inevitable due to truth claims. As this study is only limited to the Gorontalo area, the study suggests further research to conduct research in a bigger area or a different area with a different geographical situation.

Funding: This research received no external funding.

Conflicts of Interest: The authors declare no conflict of interest.

\section{References}


[1] Aksa. (2017). Gerakan Islam Transnasional: Sebuah Nomenklatur, Sejarah dan Pengaruhnya di Indonesia [Transnational Islamic Movement: A Nomenclature, History, and Influence in Indonesia]. Yupa: Historical Studies Journal, 1(1), 1-14. https://doi.org/10.26523/yupa.v1i1.6

[2] Arib, J. M. (2016). Ucapan Selamat Natal Menurut Quraish Shihab Dalam Tafsir Al Misbah: Studi Analisis Terhadap Q.S. Maryam ayat 33 [Merry Christmas Greetings According to Quraish Shihab in Tafsir Al Misbah: An Study of Surah Maryam verse 33]. Aqlam, 2(1), 11-21. https://doi.org/http://dx.doi.org/10.30984/ajip.v1i2.502

[3] Aspandi. (2018). Halal dan Haram Natal; Tinjauan Ulama Tentang Mengucapkan dan Menghadiri Natal [Halal and Haram of Christmas; Scholars Overview About Wishing Merry Christmas and Attending Christmas Parties]. AL-'ADALAH, 3(3), 225-234.

[4] Ghufron, F. (2016). Dinamika Pemikiran Islam Indonesia Dalam Perspektif Epistemologi Fiqh Dan Kontribusinya Bagi Peneguhan Semangat Kebangsan Dan Keindonesian [The Dynamics of Indonesian Islamic Thought in the Perspective of Fiqh Epistemology and Its Contribution to Strengthening the Nationalism and Indonesia Identities]. EMPIRISMA, 25(2), 83-99.

[5] Hayati, N. (2017). Konsep Khilafah IsIĀmiyyah Hizb ut-Tahrir Indonesia Kajian Living qur'an Perspektif Komunikasi [The Concept of the Islamic Khilafah Hizb ut-Tahrir Indonesia: A Study of the Living Qur'an from a Communication Perspective]. Epistemé, 12(1), 169-200. https://doi.org/doi.org/10.21274/epis.2017.12.1.169-200

[6] Hick, J. (1989). An Interpretation of Religion: Human Responses to the Transcendent. Macmillan.

[7] Ismail, Y. (2019). Postmodernism dan Perkembangan Pemikiran Islam Kontemporer [Postmodernism and the Development of Contemporary Islamic Thought]. Studi Al'Qur'an, 15(2), 235-248. https://doi.org/doi.org/10.21009/JSQ.015.2.06

[8] Junaedi, D. (2013). Memahami Teks, Melahirkan Konteks: Menelisik Interpretasi Ideologis Jamaah Tabligh [Understanding the Text, Generating Context: Examining the Ideological Interpretation of the Tablighi Jamaat]. Journal of Qur'an and Hadith Studies, 2(1), 1-17. https://doi.org/10.1548/quhas.v2i1.1274

[9] Lipoeto, M. H. (1947). Sedjarah Gorontalo, Doea Lima Pohalaa (V) [History of Gorontalo, Doea Lima Pohalaa (V)]. Gorontalo: Volks Drukkerij.

[10] Madjid, N. (2001). Cendekiawan dan Religiusitas Masyarakat [Scholars and Community Religiosity]. Paramadina.

[11] Mantau, M. (2016). Ungkapan Bermakna Budaya Dalam Upacara Adat Pernikahan Masyarakat Etnik Gorontalo [Expressions of Cultural Meaning in the Traditional Wedding Ceremony of Gorontalo Ethnical Society]. Kadera Bahasa, 8(1), 105-122. https://doi.org/https://doi.org/10.47541/kaba.v8i1.24

[12] Mulyadi. (2008). Polemik Pemikiran Filsafat Al-Ghazali dan Ibn Rusyd [Polemic Thought Philosophy Al-Ghazali and Ibn Rushd]. Tamaddun, VIII(2), 154-168.

[13] Pomalingo, S. (2019). Tuhan Agamamu Apa? Kritik atas Nalar Pemahaman Keagamaan Kita [God, What is Your Religion? Criticism of Our Religious Reasoning]. Yogyakarta: Atap Buku.

[14] Rohmana, J. A. (2017). Polemik Keagamaan Dalam Tafsir Malja' AṬ-ṬālibĪn Karya K.H. Ahmad Sanusi. Suhuf, 10(1), 25-57. https://doi.org/10.22548/shf.v10i1.207

[15] Subair, M. (2015). Ulama Kharismatik Kh. Hamrain Kau Anugrah Atas Ilmu dan Amalnya [Charismatic Ulema Kh. Hamrain Kau for the Knowledge and Deeds]. Qalam, 21(1), 45-54. http://dx.doi.org/10.31969/alq.v21i1.209

[16] Syaoki, M. (2017). Gerakan Islam Transnasional dan Perubahan Peta Dakwah Di Indonesia [Transnational Islamic Movements and Changes in the Map of Da'wah in Indonesia]. Komunike, ix(2), 167-182. https://doi.org/doi.org/10.20414/jurkom.v9i02.1288

[17] Zaeny, A. (2016). Gerakan Dan Strategi Perjuangan Jama'atut Tabligh [Movement and Strategy of the Tablighi Jamaat's Struggles]. Jurnal TAPIs, 12(2), 1-17. https://doi.org/doi.org/10.24042/tps.v12i2.1616 